\title{
ANALISIS KECELAKAAN PENERBANGAN DI INDONESIA UNTUK PENINGKATAN KESELAMATAN PENERBANGAN
}

\author{
Eko Poerwanto ${ }^{1}$, Uyuunul Mauidzoh ${ }^{2}$ \\ Prodi Teknik Industri \\ Sekolah Tinggi Teknologi Adisutjipto \\ Jalan Janti Komplek Lanud. Adisutjipto, Blok R, Yogyakarta \\ 1ekoevtas@gmail.com
}

\begin{abstract}
Achievement level of aviation safety can be achieved with the proper function of all components of the system in the aviation industry which consists of airport operators, airline operators, air traffic operators and aircraft maintenance operator, as well as the regulations set by the regulator. Every incident should be investigated aviation accidents to find the cause. This is to provide appropriate recommendations so that the same airline accident does not happen again. The increasing number of flights that are needed with safety guarantees. So it is importance to analyzed routine flight accident to improve the safety performance of airlines.

This research is descriptive analysis with qualitative methods. Flight accidents data that have investigated from NTSC and DGCA grouped causes are then recommendations have been made by the NTSC also grouped for each operator stakeholders. Improved system of aviation safety in Indonesia can be done with a thorough analysis based on the results of investigation of NTSC whose recommendations have been given to all stakeholders in the aviation industry.

The results showed that the causes of flight accidents in Indonesia is dominated by the human factor the percentage reached $60 \%$. The highest number of the recommendations given by the NTSC to DGCA as many as 208 recommendations during the period 2007-2014 but the trend of declining. On other side of the trend of the recommendations given to aviation operators showed an increase. This shows an increase in the duty on DGCA to always supervise, and set the standard flight operations carried out by several airline operators in Indonesia.
\end{abstract}

Keywords: Safety Aviation, Accident, Safety Level

\begin{abstract}
Abstrak
Pencapaian tingkat keselamatan penerbangan hanya dapat dicapai dengan berfungsinya seluruh komponen sistem pada industri penerbangan yang terdiri dari operator bandara, operator maskapai penerbangan, operator lalu lintas udara dan operator perawatan pesawat udara, serta regulasi yang ditetapkan oleh regulator. Setiap kejadian kecelakaan penerbangan harus diinvestigasi untuk menemukan penyebab utamanya. Hal ini untuk memberikan rekomendasi yang tepat sehingga kecelakaan penerbangan yang sama tidak terulang kembali. Semakin meningkatnya jumlah penerbangan yang dibutuhkan saat ini harus dibarengi dengan jaminan keselamatan. Berkaitan dengan hal tersebut pentingnya dilakukan analisis kecelakaan penerbangan yang rutin dalam periode waktu tertentu untuk memperbaiki kinerja keselamatan penerbangan.

Penelitian ini merupakan analisis deskriptif dengan metode kualitatif. Data kecelakaan penerbangan yang telah terinvestigasi dari KNKT dan DKPPU dikelompokkan penyebabnya kemudian rekomendasi yang telah dibuat oleh KNKT juga dikelompokkan untuk tiap operator pemangku kepentingan. Perbaikan sistem keselamatan penerbangan di Indonesia dapat dilakukan
\end{abstract}


dengan analisis secara menyeluruh berdasarkan hasil investigasi KNKT yang rekomendasinya telah diberikan kepada seluruh pemangku kepentingan pada industri penerbangan.

Hasil penelitian menunjukkan bahwa penyebab kecelakaan penerbangan di Indonesia yang dominan adalah faktor manusia persentasenya mencapai $60 \%$. Jumlah rekomendasi yang terbanyak diberikan oleh KNKT kepada Ditjen Perhubungan Udara yaitu sebanyak 208 rekomendasi selama periode tahun 2007-2014 tetapi kecenderungan trennya menurun. Pada sisi yang lain tren rekomendasi yang diberikan ke operator penerbangan menunjukkan kenaikan. Hal ini menunjukkan peningkatan tugas pada Ditjen Perhubungan Udara untuk selalu mengawasi standar operasional penerbangan pada beberapa operator penerbangan di Indonesia.

Kata kunci: Keselamatan Penerbangan, Kecelakaan, Peringkat Keselamatan

\section{Pendahuluan}

Penyebab kecelakaan pesawat biasanya diakibatkan oleh 3 faktor utama yaitu: faktor teknis, faktor cuaca dan faktor kesalahan manusia (human error). Berdasarkan buku Statistik Perhubungan 2013, data kecelakaan pesawat terbang untuk rentang waktu 2009 - 2013 sebagai berikut:

Tabel 1. Data Kecelakaan dan Serius Insiden pada Pesawat Udara di Indonesia

(Aircraft Accident and Serious Incident Data in Indonesia 2009 - 2013)

\begin{tabular}{|c|c|c|c|c|c|c|c|c|}
\hline No. & $\begin{array}{c}\text { Eraial } \\
\text { Descriphiow }\end{array}$ & $\begin{array}{l}\text { Glafik Tren } \\
\text { Trend' Groph }\end{array}$ & $\begin{array}{c}\text { Saman } \\
\text { LFitit }\end{array}$ & 2009 & 2010 & 1011 & 2012 & 2013 \\
\hline I & Serius Inciden / Seriau Incident & & Krjadian / Care & 12 & 9 & 17 & 15 & 17 \\
\hline 2 & Kecelakan /Ancidens & & Kejadian ' Cate & 10 & 8 & 17 & 8 & s \\
\hline
\end{tabular}

Keterangan : Berdasarkan PM No. 6 Tahun 2014 bahwa sumber data kecelakaan hanya akan dikeluarkan oleh KNKT

Sumber: Dit. Kelaikan Udara Dan Pengoperasian Pesawat Udara, Ditjen Hubud/ Directorate of Airworthiness And Aircraft Operations, Directorate General of Civil Aviation, Ministry of Transportation (diolah kembali) recompiled)

Berdasarkan data tersebut di atas, kecelakaan penerbangan di Indonesia yang masuk kelompok serius insiden lebih tinggi daripada kelompok accident. Hal ini merupakan masalah yang cukup rumit. Mekanisme penyelidikan yang dilakukan KNKT menggunakan pedoman berdasarkan pada peraturan nasional dan internasional yang konsisten. Tujuan tunggal penyelenggaraan penyelidikan kecelakaan oleh KNKT adalah mencari setiap penyebab yang berpengaruh terhadap terjadinya kecelakaan. Selanjutnya hasil dari penyelidikan ini dapat dipergunakan untuk meningkatkan kondisi dan tindakan keselamatan penerbangan guna mencegah kecelakaan dengan penyebab yang sama dikemudian hari. Berdasarkan uraian tersebut maka rekomendasi yang diberikan KNKT adalah tidak komprehensif, hanya berdasarkan atas dasar tiap kejadian, padahal kecelakaan pesawat terbang yang paling penting adalah dengan mengungkap kondisi "Latent/tersembunyi" yang harus diungkap, maka analisis yang komprehensif diperlukan untuk mengamati akar permasalahan yang paling dalam.

Tujuan penyelenggaraan penerbangan nasional dalam Undang-undang Nomor 1 Tahun 2009 tentang Penerbangan diantaranya adalah mewujudkan penyelenggaraan penerbangan yang tertib, teratur, selamat, aman, nyaman, dengan harga wajar dan menghindari praktek 
persaingan usaha yang tidak sehat. Penyelenggaraan yang selamat dan aman diatas, merupakan jaminan terpenting dalam penerbangan, ini mengingat akan bahaya dan kecelakaan yang mudah ditimbulkan oleh penggunaan suatu pesawat udara.

Dari 10 negara di ASEAN, level keselamatan penerbangan Indonesia berada di posisi terakhir. Poin yang dinilai dalam audit ini mulai dari kondisi regulator, lisensi, operasional, kebandarudaraan, navigasi udara, penanganan kecelakaan, hingga kelengkapan penerbangan. Hal sama dikeluarkan oleh otoritas penerbangan Amerika Serikat, Federal Aviation Administration (FAA). FAA memberi peringkat level 2 atau di bawah standar untuk kategori International Aviation Safety Assessment (IASA) kepada Indonesia. Sementara menurut Undang-Undang No. 1 Tahun 2009 tentang Penerbangan pada Pasal 1, Ayat 48 menyatakan bahwa "Keselamatan Penerbangan adalah suatu keadaan terpenuhinya persyaratan keselamatan dalam pemanfaatan wilayah udara, pesawat udara, bandar udara, navigasi penerbangan, serta fasilitas penunjang dan fasilitas umum lainnya." Berkaitan dengan ini berarti tingkat keselamatan penerbangan dapat dicapai hanya dengan berfungsinya semua bagian dari industri penerbangan.

Berdasarkan beberapa uraian tersebut di atas, maka penting sekali melakukan penelitian "Analisis Kecelakaan Penerbangan di Indonesia untuk Peningkatan Keselamatan Penerbangan", sehingga dalam kurun waktu mendatang peringkat keselamatan penerbangan di Indonesia dapat naik dan dapat mempertahankannya.

\section{Metode Penelitian}

Tujuan penelitian adalah: 1. dapat menentukan pengklasifikasian penyebab kecelakaan penerbangan di Indonesia dan menentukan penyebab kecelakaan yang dominan terjadi; 2 . dapat menentukan rekomendasi yang tepat, sehingga dapat meningkatkan peringkat keselamatan penerbangan di Indonesia. Jenis penelitian adalah analisis deskriptif dengan metode kualitatif. Penelitian diawali dengan observasi ke KNKT dan Ditjen Perhubungan Udara. Kedua lembaga ini yang berwenang dalam menginvestigasi adanya kejadian dan kecelakaan pada penerbangan. Data yang didapat dari kedua lembaga ini diolah dan dianalisis penyebab adanya kejadian dan kecelakaan penerbangan. Data resmi dari KNKT merupakan data final hasil investigasi dari tahun 2007 sampai dengan tahun 2014. Data tersebut yang menjadi dasar analisis yang digunakan dalam penelitian ini. Analisis yang dilakukan ada beberapa hal yaitu: 1 . Penyebab adanya kejadian dan kecelakaan; 2 . Analisis rate of accident; 3. Analisis lokasi/tempat yang paling tinggi adanya kejadian dan kecelakaan; dan 4. Analisis terhadap rekomendasi yang telah dikeluarkan oleh KNKT. Beberapa analisis yang dilakukan dapat dihasilkan kesimpulan dan saran untuk menentukan prioritas perbaikan yang perlu dilakukan untuk seluruh pemangku kepentingan dalam industri penerbangan di Indonesia.

Dalam rangka untuk menetapkan target kinerja keselamatan, perlu terlebih dahulu memutuskan indikator kinerja keselamatan yang tepat. Indikator kinerja keselamatan umumnya dinyatakan dalam frekuensi terjadinya peristiwa yang mengakibatkan beberapa kerusakan. Indikator kinerja keselamatan yang bisa digunakan misalnya :
a. kecelakaan pesawat per 10000 pergerakan pesawat
b. kecelakaan pesawat fatal per tahun
c. insiden serius per 10000 pergerakan.

Setelah memutuskan pada indikator keselamatan yang tepat, itu kemudian perlu untuk memutuskan apa merupakan hasil diterima atau tujuan. Misalnya, ICAO telah menetapkan 
target kinerja keselamatan global di tujuan dari Rencana Keselamatan Penerbangan Global (GASP). Ini adalah:

a. untuk mengurangi jumlah kecelakaan dan kematian di seluruh dunia terlepas dari volume lalu lintas udara;

b. untuk mencapai penurunan yang signifikan tingkat kecelakaan, terutama di daerah di mana tetap tinggi.

Hasil keselamatan yang diinginkan dapat dinyatakan baik secara absolut atau relatif. Target global dari ICAO adalah contoh dari target relatif. Target relatif juga bisa memasukkan persentase yang diinginkan pengurangan kecelakaan atau jenis tertentu dari kejadian-kejadian keselamatan dalam jangka waktu yang ditetapkan. Misalnya, target kecelakaan penerbangan adalah 0,1 kecelakaan untuk 10.000 pergerakan pesawat udara.

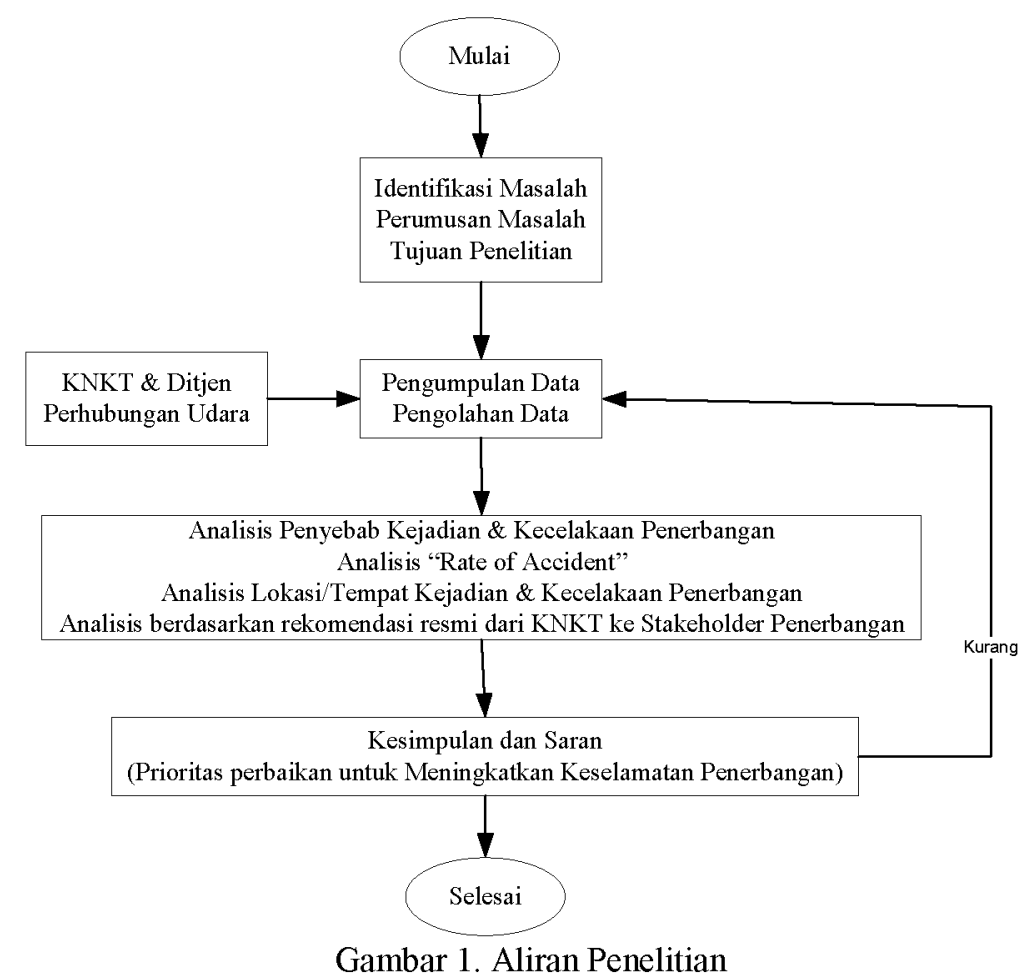

\section{Hasil dan Pembahasan}

\subsection{Kecelakaan Penerbangan}

Berdasarkan International Investigation Standards Annex 13-Aircraft Accident and Incident Investigation, tenth Edition-July 2010, incorporating Amendment 14 and supplement, Undang-Undang Nomor: 1 Tahun 2009 tentang Penerbangan dan Peraturan Pemerintah Republik Indonesia nomor 62 Tahun 2013, tentang Investigasi Kecelakaan Transportasi, Pasal 9 menyatakan bahwa Kecelakaan Pesawat Udara dapat terdiri atas: a. Pesawat Udara yang jatuh pada saat tinggal landas, lepas landas, atau selama penerbangan; b. tabrakan antar Pesawat Udara atau antar Pesawat Udara dengan fasilitas di bandar udara; c. Pesawat Udara yang hilang atau tidak dapat diketemukan; dan/atau; d. Pesawat Udara yang mengalami Kejadian Serius (serious incident).

Pada penelitiannya (Sentot S., 2012) menyatakan bahwa: insiden (incident) dapat berupa sebagai suatu kejadian yang hampir atau nyaris (near-miss) menyebabkan terjadinya 
suatu kecelakaan. Dengan melihat definisi dari accident (kecelakaan) dan incident (insiden) yang dijelaskan diatas, maka dapat disimpulkan dengan tujuan untuk memudahkan pengertian dari kedua istilah tersebut diatas. Kesimpulannya adalah sebagai berikut:

a. Accident dan incident merupakan kejadian yang tidak diinginkan atau tidak direncanakan.

b. Accident dan incident disebabkan oleh banyak faktor dan memiliki urutan kejadian yang memberikan dampak atau efek berupa: injury, disease, damage, near miss dan loss.

c. Semua kecelakaan (accident) dapat dikatakan sebagai incident (insiden)

d. Semua insiden (incident) tidak dapat dikatakan sebagai kecelakaan (accident)

e. Semua injury diakibatkan oleh terjadinya accident (kecelakaan)

f. Semua kecelakaan (accident) tidak selalu menghasilkan injury

Hazard adalah faktor intrinsik yang melekat pada sesuatu berupa barang atau kondisi dan mempunyai potensi menimbulkan efek kesehatan maupun keselamatan pekerja serta lingkungan yang memberikan dampak buruk. Hazard keselamatan dan kesehatan adalah setiap kondisi atau perilaku di lingkungan penerbangan yang sendirian atau bersama sama dengan variabel lain berpotensi dapat menimbulkan penyakit akibat kerja atau kecelakaan. Dalam kesehatan kerja pengertian hazard identik dengan faktor resiko yakni kondisi atau perilaku yang mengandung probabilitas bagi timbulnya penyakit dan kecelakaan.

Resiko (risk) adalah ukuran kemungkinan kerugian yang timbul dari sumber bahaya (hazard) tertentu yang terjadi atau dengan kata lain resiko adalah probabilitas kerusakan atau kerugian dari bahaya yang melekat pada spesifik individu atau kelompok yang terpapar oleh hazard tersebut. Resiko merupakan akumulasi dari potensi hazard, konsekuensi yang diakibatkanya, durasi pemaparan dan probabilitas yang ditimbulkanya. Beberapa aspek yang dapat dipertimbangkan terhadap adanya resiko yaitu; variasi kerentanan individu, jumlah orang yang terpajan, frekuensi pemajanan, derajat resiko individu, kemungkinan eliminasi dan substitusi, kemungkinan pencapaian suatu keadaan yang aman, public opinion, pressure group dan social responsibility. Ada 3 aspek utama terhadap kecelakaan (accident) yaitu :

a. Keadaan apapun yang membahayakan pada tempat kerja mupun dilingkungan kerja. Bahaya ini untuk manusia menimbulkan cedera (injury) dan sakit (illness).

b. Cedera dan sakit adalah hasil dari kecelakaan akan tetapi kecelakaan tidak terbatas pada cedera atau sakit saja.

c. Jika dalam suatu kejadian menyebabkan kerusakan atau kerugian (loss) tetapi tidak ada cedera pada manusia, hal ini termasuk juga kecelakaan. Kecelakaan dapat menyebabkan bahaya pada orang, kerusakan pada peralatan atau barang dan terhentinya proses pekerjaan.

\subsection{Investigasi Kecelakaan}

Sesuai dengan Peraturan Pemerintah Nomor: 62 Tahun 2013, pasal 22 yang menyatakan bahwa Badan Usaha Angkutan Udara, penyedia jasa penerbangan atau Kementerian yang menyelenggarakan urusan pemerintahan dibidang transportasi wajib memberitahukan adanya kecelakaan atau kejadian serius pesawat udara kepada KNKT. Alur pelaporan kecelakaan pesawat udara sesuai gambar dibawah ini: 


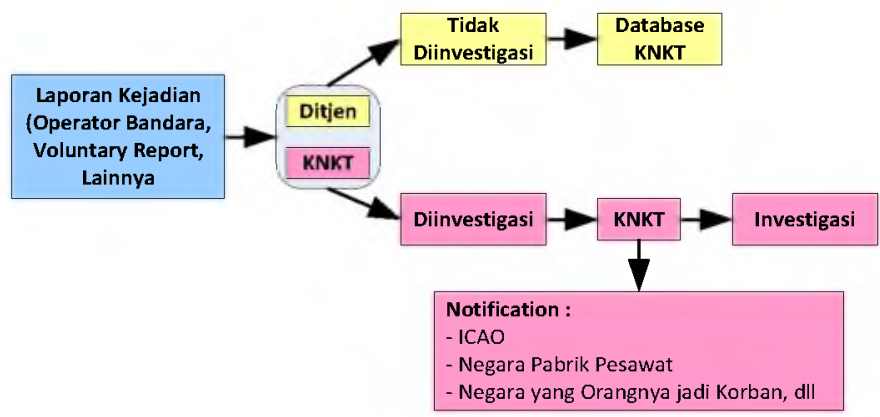

Gambar 2. Alur pelaporan kecelakaan pesawat udara Sumber: Buku Saku KNKT

Berdasarkan gambar alur pelaporan adanya kecelakaan pesawat udara yang harus dilakukan oleh pemangku kepentingan kepada KNKT dan Ditjen Perhubungan Udara menunjukkan bahwa tidak adanya sistem informasi yang yang terintegrasi pada transportasi udara. Hal ini sangat menyulitkan proses investigasi yang harus dilakukan oleh KNKT. Sebuah penyelidikan kecelakaan dapat dilihat sebagai sebuah analisis keselamatan, mengingat luasnya definisi yang diterapkan. Sebuah penyelidikan menyeluruh dapat memberikan informasi yang berguna tentang sistem di mana kecelakaan terjadi dan bagaimana mencegah lebih lanjut kejadian kecelakaan. Kerugian dari perspektif metodologis adalah bahwa titik awal untuk penyelidikan adalah peristiwa tunggal atau acak.

Ada beberapa metode untuk investigasi kecelakaan yang didasarkan pada prinsip yang beragam. Pemilihan metode yang tepat dan pendekatan tergantung pada alasan untuk penyelidikan. Contoh tujuan dan situasi adalah:

a. Mencari tahu apa yang terjadi dengan penyelidikan cepat dan sederhana.

b. Menentukan tanggung jawab untuk kecelakaan yang mungkin menyangkut peraturan, kompensasi finansial kepada orang yang terluka dan sebagainya.

b. Dalam kasus kecelakaan besar, memperoleh pemahaman yang memuaskan dan penjelasan dan mengejar penyelidikan secara menyeluruh dan rinci.

c. Melakukan penelitian sebagai bagian dari rencana untuk mengumpulkan informasi tentang kelemahan dalam sistem.

d. Dalam sistem yang direncanakan memiliki tingkat keselamatan yang tinggi, dianggap kecelakaan sebagai kegagalan sistem. Penyelidikan akan memberikan kesempatan untuk meningkatkan sistem.

Saat ini Dirjen Perhubungan Udara mempunyai State Safety Program (SSP) yaitu sebuah program yang bertujuan untuk mempromosikan pencegahan kecelakaan dengan analisis data kecelakaan dan insiden dan didukung oleh pertukaran informasi yang cepat. Program ini juga telah disahkan dalam Undang-undang No. 1 Tahun 2009 tentang Penerbangan. Tetapi sangat disayangkan, program ini belum berjalan optimal, karena tidak bersifat aktif dalam penyampaian informasi, baik informasi tentang keselamatan dan keamanan pada industri penerbangan. Salah satu alasan kepasifan sistem SSP adalah kurangnya integrasi data dari pemangku kepentingan terdekat dengan pengguna yaitu operator. Operator dapat bertindak sebagai data collector tetapi proses integrasi data rentan terhadap isu interoperabilitas sistem dan keamanan data. Proses integrasi yang dilakukan mempertimbangkan faktor heterogenitas sistem. Operator mengembangkan aplikasi pada platform yang berbeda-beda dan bahasa pemrograman yang berbeda-beda pula, sehingga 
sangat perlu untuk membuat kesepakatan (standar) yang diterima dari provider ke consumer. Standar ini tertuang dalam sebuah protokol web service baik Simple Object Access Protocol (SOAP) atau Restfull.

\section{A. Tahapan Proses Investigasi yang dilakukan oleh KNKT}

Sesuai peraturan perundang-undangan yang berlaku, KNKT wajib melakukan investigasi terhadap kejadian yang masuk dalam kategori Accident, Serious Incident dan kejadian yang mengarah timbulnya Serious Incident.

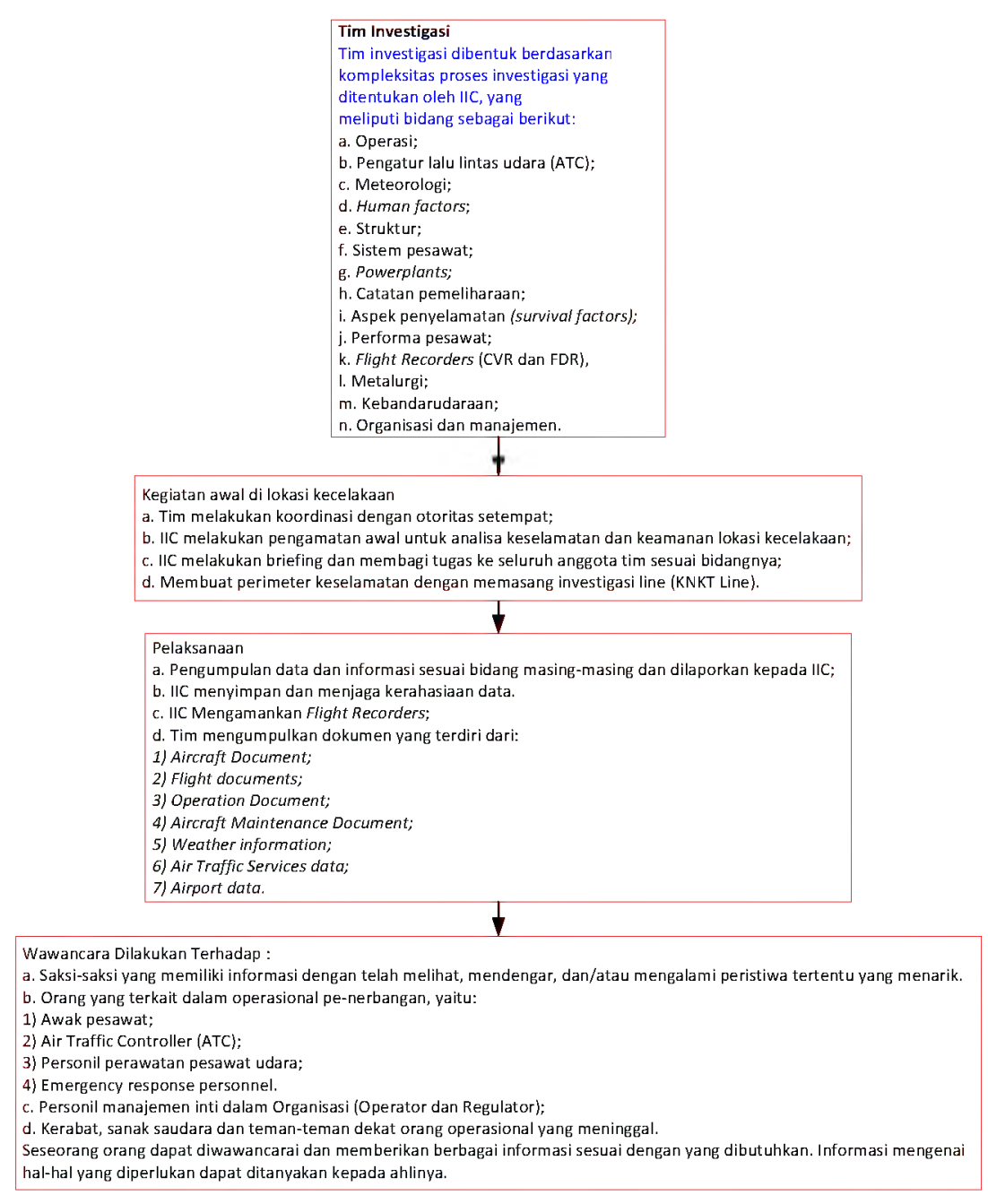

Gambar 3. Tahapan Proses Pelaksanaan Investigasi oleh KNKT

\section{B. Tahapan Proses Penyusunan Laporan Hasil Investigasi yang dilakukan oleh KNKT.}

Setelah melakukan proses investigasi, Tim yang dibentuk oleh KNKT diwajibkan menyusun laporan hasil investigasi dengan tahapan sebagai berikut: 


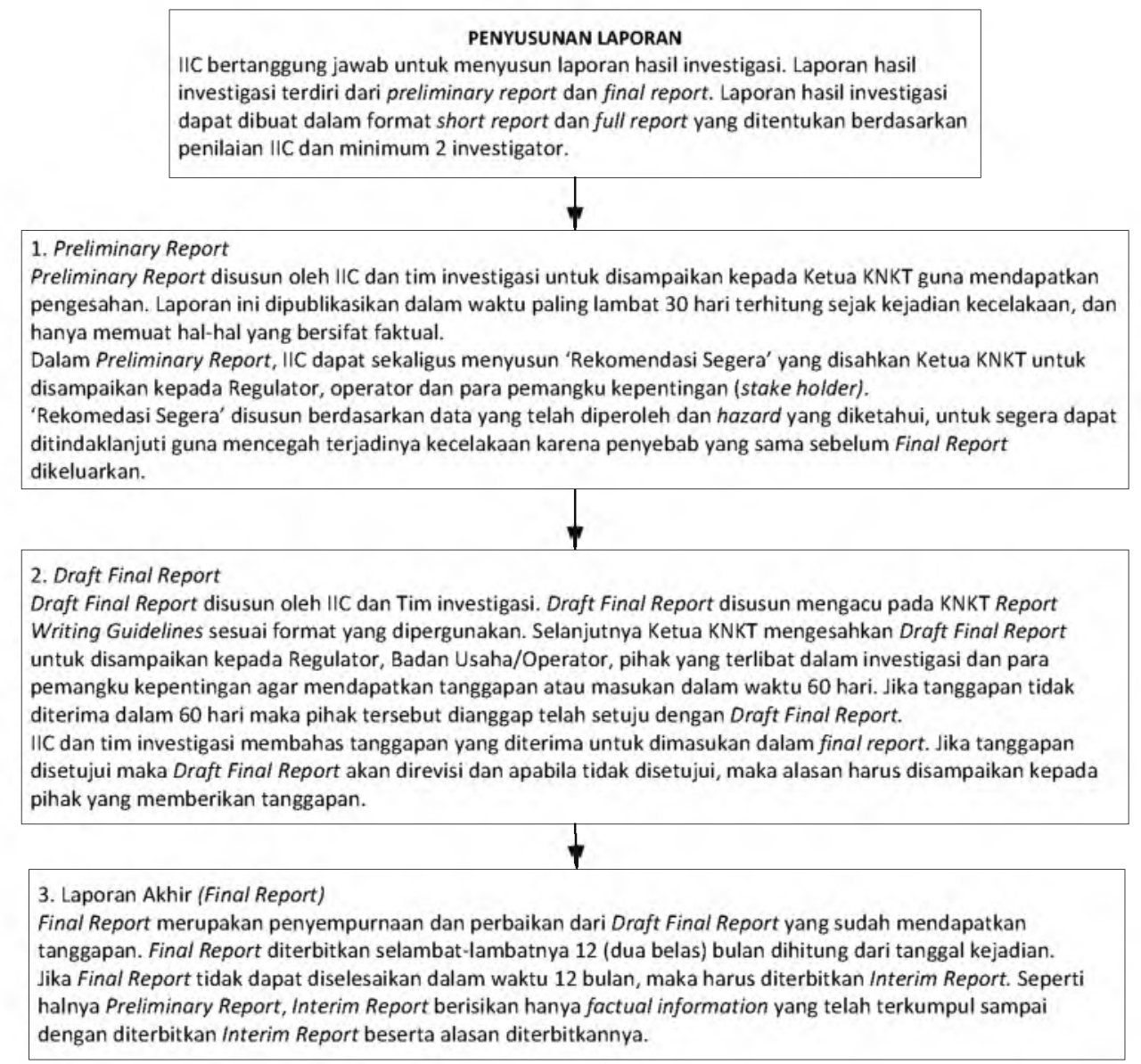

Gambar 4. Tahapan proses penyusunan Laporan Hasil Investigasi oleh KNKT

Berdasarkan tahapan proses penyusunan laporan hasil investigasi kecelakaan penerbangan yang dilakukan oleh KNKT, maka dapat dipastikan bahwa data resmi kejadian kecelakaan yang telah diinvestigasi dapat dikeluarkan secara resmi oleh KNKT paling cepat membutuhkan waktu 15 (lima belas) bulan atau setahun lebih. Hal inilah yang menjadi dasar penyusunan data penelitian analisis kecelakaan penerbangan di Indonesia yang dilakukan saat ini mengambil data untuk rentang waktu dari tahun 2007 sampai dengan 2014, dengan rekap data sebagai berikut :

Tabel 2. Data Kecelakant Penarbangan Kotnersial Berjadwal dan Tidak-Berjadwal Yang Dintestigasi KNKT 2007-2014

\begin{tabular}{|c|c|c|c|c|c|c|}
\hline \multirow{2}{*}{$T=\ln$} & \multirow{2}{*}{$\begin{array}{c}\text { Jrmistat } \\
\text { Kenelakiam }\end{array}$} & \multicolumn{2}{|c|}{ Teris Kenelakand } & \multicolumn{2}{|c|}{ Kontan Tina } & \multirow{2}{*}{ Fikbowent: } \\
\hline & & ficriden & $\begin{array}{l}\text { Serious } \\
\text { Shcident }\end{array}$ & 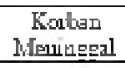 & $\begin{array}{c}\text { Karous Luka- } \\
\text { lukia }\end{array}$ & \\
\hline 2007 & 21 & 15 & 6 & $12 \Xi$ & 10 & $9 \mathrm{E}$ \\
\hline 2008 & 21 & $1+$ & 7 & 6 & 2 & 83 \\
\hline 2009 & 21 & 13 & $\mathrm{~B}$ & 40 & 9 & $4 B$ \\
\hline 2010 & 18 & $\mathrm{~B}$ & 80 & 5 & 46 & 39 \\
\hline 2011 & 32 & 19 & 13 & 71 & 8 & $9 \mathrm{~B}$ \\
\hline 2012 & 29 & 13 & $\square 6$ & 58 & 9 & 56 \\
\hline 2013 & 29 & 6 & 23 & 2 & 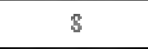 & $T 7$ \\
\hline 2014 & 30 & $?$ & 23 & 169 & 6 & $1+4$ \\
\hline Tota] & 201 & 95 & 106 & 476 & 98 & 513 \\
\hline
\end{tabular}

Sumber : Database KNKT 31 Desember 2014 (diolah) 
Jenis klasifikasi kejadian dan kecelakaan penerbangan yang menjadi perhatian KNKT adalah "accident dan serious incident". Kejadian serius atau serious incident sangat penting untuk diperhatikan karena angka ini menunjukkan potensi adanya accident. Analisis klasifikasi "accident dan seious incident" adalah sebagai berikut:

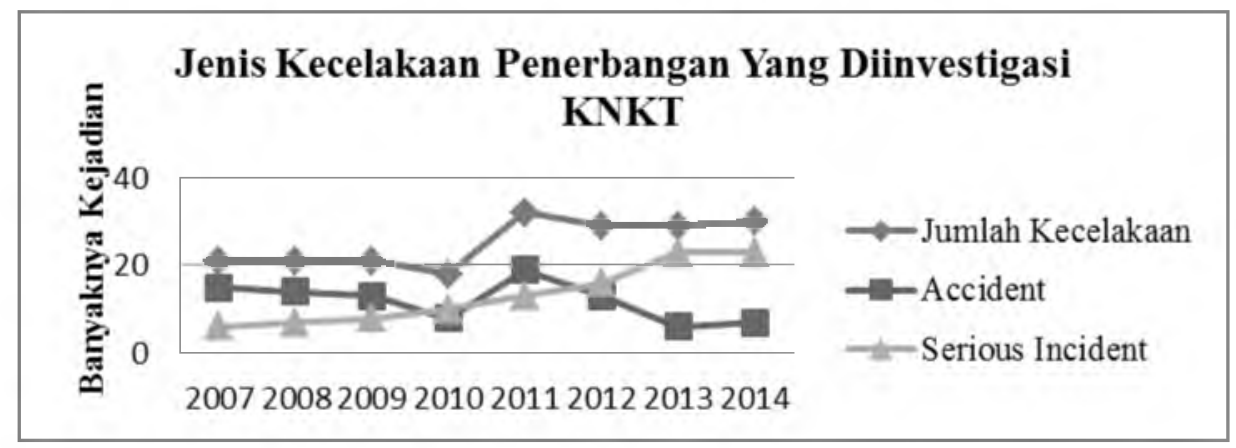

Gambar 5. Grafik jenis kecelakaan penerbangan yang telah diinvestigasi KNKT Sumber : Database KNKT 31 Desember 2014 (diolah)

Berdasarkan gambar grafik jenis kecelakaan penerbangan yang telah diinvestigasi oleh KNKT selama periode tahun 2007 sampai dengan tahun 2014, menunjukkan bahwa "accident" penerbangan cenderung menurun, tetapi perlu diwaspadai bahwa "serious incident" cenderung mengalami peningkatan. Kondisi ini menunjukkan potensi accident akan mengalami peningkatan jika tidak dilakukan usaha preventif yang serius. Ditjen Perhubungan Udara dalam hal ini Direktorat Kelaikudaraan dan Pengoperasian Pesawat Udara harus serius, karena lembaga ini yang mempunyai tugas melaksanakan perumusan dan pelaksanaan kebijakan, penyusunan norma, standar, prosedur, dan kriteria, pemberian bimbingan teknis dan supervisi, serta evaluasi dan pelaporan di bidang kelaikudaraan dan pengoperasian pesawat udara.

Analisis berikutnya adalah faktor penyebab adanya "accident dan serious incident". Berdasarkan hasil investigasi KNKT untuk kurun waktu tahun 2007 sampai dengan tahun 2014 menunjukkan bahwa persentase terbesar adalah disebabkan oleh faktor manusia atau human factor. Hal ini dapat diuraikan sebagai berikut dibawah ini:

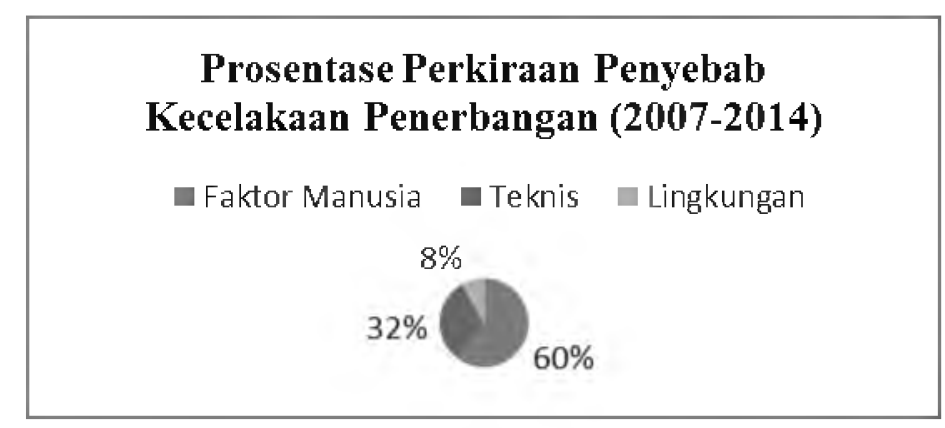

Gambar 6. Persentase perkiraan penyebab kecelakaan penerbangan di Indonesia.

Sumber : Database KNKT 31 Desember 2014 (diolah)

Hasil investigas KNKT berkaitan penyebab adanya kecelakaan penerbangan di Indonesia antara periode tahun 2007 sampai dengan tahun 2014 sebagai berikut: 
Tabel 3. Perkiraan Faktor Penyebab Kecelakaan Penerbangan Talinu 2007 - 2014

\begin{tabular}{|c|c|c|c|}
\hline \multirow{2}{*}{ T: allutu } & \multicolumn{3}{|c|}{ Ferkiran Faktor Pengebab } \\
\hline & Falt or Mathis & Telinis & Linghatuman \\
\hline 2007 & 15 & 5 & 1 \\
\hline 2008 & 6 & 12 & 3 \\
\hline 2009 & 12 & 5 & 0 \\
\hline 2010 & 9 & 5 & 1 \\
\hline 2011 & 23 & $\mathrm{i}$ & 2 \\
\hline 2012 & 21 & 4 & 4 \\
\hline 2013 & 9 & 4 & 2 \\
\hline 2014 & 1 & 1 & 0 \\
\hline Total & 96 & 50 & 13 \\
\hline
\end{tabular}

Ket : Beberapa kecelakaan mash dalam proses invesitigasi, sehingega faktor penyebab belutu dapat ditentukan. Surrber : Database KNKT 31 Desember 2014 (diolali)

Berdasarkan tabel perkiraan penyebab kecelakaan penerbangan di Indonesia antara periode tahun 2007 sampai dengan tahun 2014, jika dianalisis dalam bentuk grafik adalah sebagai berikut:

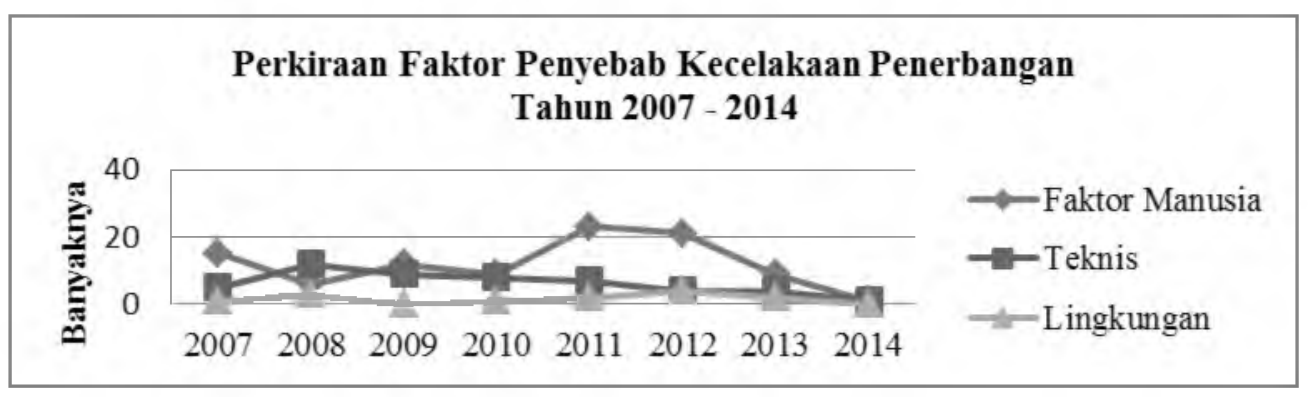

Gambar 7. Grafik perkiraan penyebab kecelakaan penerbangan di Indonesia

Berdasarkan gambar grafik perkiraan penyebab kecelakaan penerbangan di Indonesia dapat dilihat bahwa faktor yang paling dominan pada tiap tahun kejadian kecelakaan penerbangan antara tahun 2007 - 2014 adalah faktor manusia. Kondisi ini menunjukkan adanya kendala pada aspek manusia pada industri penerbangan di Indonesia. Ditjen Perhubungan Udara dalam hal ini Direktorat Kelaikudaraan dan Pengoperasian Pesawat Udara harus serius, karena lembaga ini yang mempunyai tugas melaksanakan perumusan dan pelaksanaan kebijakan, penyusunan norma, standar, prosedur, dan kriteria, pemberian bimbingan teknis dan supervisi, serta evaluasi dan pelaporan di bidang kelaikudaraan dan pengoperasian pesawat udara.

Analisis berikutnya rate of accident menunjukkan bahwa kejadian kecelakaan penerbangan untuk jumlah produksi jam terbang dalam satu periode. Dalam rangka untuk menetapkan target kinerja keselamatan, perlu terlebih dahulu memutuskan indikator kinerja keselamatan yang tepat. Indikator kinerja keselamatan umumnya dinyatakan dalam frekuensi terjadinya peristiwa yang mengakibatkan beberapa kerusakan. Indikator kinerja keselamatan yang bisa digunakan misalnya:
a. Kecelakaan pesawat per 10.000 pergerakan pesawat.
b. Kecelakaan pesawat fatal per tahun.
c. Insiden serius per 10.000 pergerakan.

Setelah memutuskan pada indikator keselamatan yang tepat, itu kemudian perlu untuk memutuskan apa merupakan hasil diterima atau tujuan. Misalnya, ICAO telah menetapkan 
target kinerja keselamatan global di tujuan dari Rencana Keselamatan Penerbangan Global (GASP). Ini adalah:

a. untuk mengurangi jumlah kecelakaan dan kematian di seluruh dunia terlepas dari volume lalu lintas udara;

b. untuk mencapai penurunan yang signifikan tingkat kecelakaan, terutama di daerah di mana tetap tinggi.

Hasil keselamatan yang diinginkan dapat dinyatakan baik secara absolut atau relatif. Target global dari ICAO adalah contoh dari target relatif. Target relatif juga bisa memasukkan persentase yang diinginkan pengurangan kecelakaan atau jenis tertentu dari kejadian-kejadian keselamatan dalam jangka waktu yang ditetapkan. Misalnya, target kecelakaan penerbangan adalah 0,1 kecelakaan untuk 10.000 pergerakan pesawat udara. berikut:

KNKT menggunakan formula dalam menghitung rate of accident adalah sebagai

$$
\text { Rate of Accident }=\frac{\text { Jumlah Kacelakan }}{\text { Jumiah Produksi Jam Tarbang }} \times 100,000
$$

Tabrel 4. Rafe of Accident Penerbangan di Inctonesia Tahun $2007-2014$

\begin{tabular}{|c|c|c|c|c|c|c|c|c|}
\hline \multirow{2}{*}{ Ketergngail } & \multicolumn{8}{|c|}{ 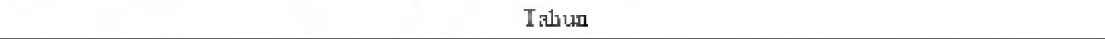 } \\
\hline & 2007 & 2008 & 2009 & 29010 & 2011 & 2012 & 2013 & 2014 \\
\hline $\begin{array}{l}\text { Iotal } \\
\text { Kecelakaw }\end{array}$ & 21 & 21 & 21 & 18 & 32 & 29 & 29 & 30 \\
\hline Ancident & 15 & 14 & 13 & 8 & 19 & 13 & 5 & 7 \\
\hline $\begin{array}{l}\text { Iotal } \\
\text { Flying } \\
\text { Hous } \\
\end{array}$ & 510.137 & 477.556 & 753.425 & 671.204 & 758.318 & $1.893,031$ & $1,082,506$ & 920.357 \\
\hline $\begin{array}{l}\text { Total } \\
\text { Passengevs }\end{array}$ & 39.162 .332 & $37,405,43 ?$ & $3.808,033$ & $47,252,237$ & $49.722,426$ & $59: 137.897$ & $53,811,687$ & $60.089,283$ \\
\hline $\begin{array}{l}\text { Rite of } \\
\text { Accident } \\
\text { Serious } \\
\text { Incident }\end{array}$ & 4.12 & 4.40 & 2.79 & 2.58 & 4.22 & 1.53 & 2.68 & 3.26 \\
\hline $\begin{array}{l}\text { Rite of } \\
\text { Accident }\end{array}$ & 2.94 & 2.93 & 1.73 & 1.19 & 2.51 & 0.69 & 0.5 & 0.76 \\
\hline
\end{tabular}

Berdasarkan data rate of accident penerbangan di Indonesia periode tahun 2007-2014 dapat dianalisis sebagai berikut:

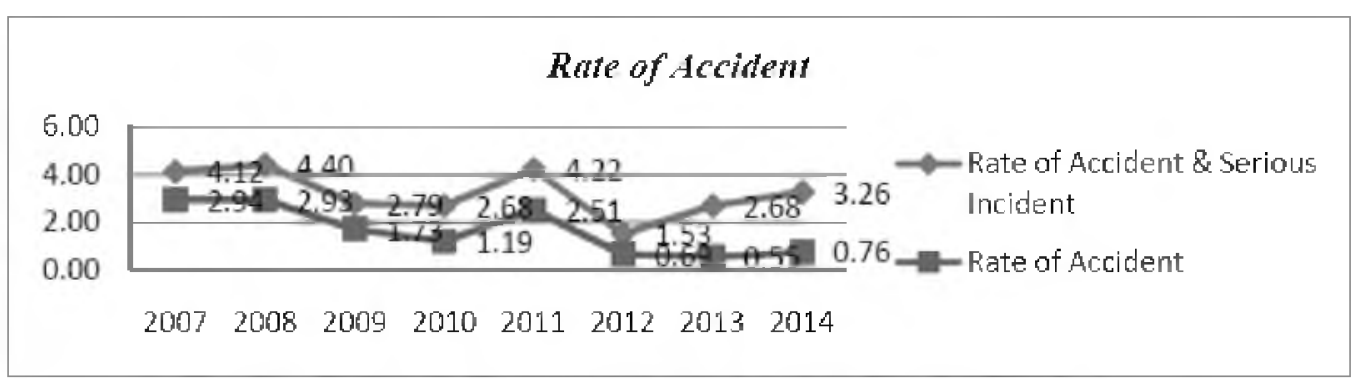

Gambar 8. Grafik Rate of Accident ant ara talnun 2007-2014

Berdasarkan gambar grafik rate of accident di atas menunjukkan tren penurunan nilainya, tetapi jika melihat nilai dari Serious Incident yang cenderung meningkat, maka jika pengawasan keselamatan berkurang akan berdampak pada nilai accident yang meningkat. Ditjen Perhubungan Udara dalam hal ini Direktorat Kelaikudaraan dan Pengoperasian Pesawat Udara harus serius, karena lembaga ini yang mempunyai tugas melaksanakan 
perumusan dan pelaksanaan kebijakan, penyusunan norma, standar, prosedur, dan kriteria, pemberian bimbingan teknis dan supervisi, serta evaluasi dan pelaporan di bidang kelaikudaraan dan pengoperasian pesawat udara.

Analisis berikutnya adalah lokasi/tempat terjadinya accident dan serious incident pada industri penerbangan di Indonesia. Berdasarkan data hasil investigasi yang telah dilakukan KNKT sebaran kejadian accident dan serious incident penerbangan di wilayah Indonesia adalah sebagai berikut:

\section{PETA PERSEBARAN KECELAKAAN PENERBANGAN YANG DIINVESTIGASI KNKT TAHUN 2007 - 2014}

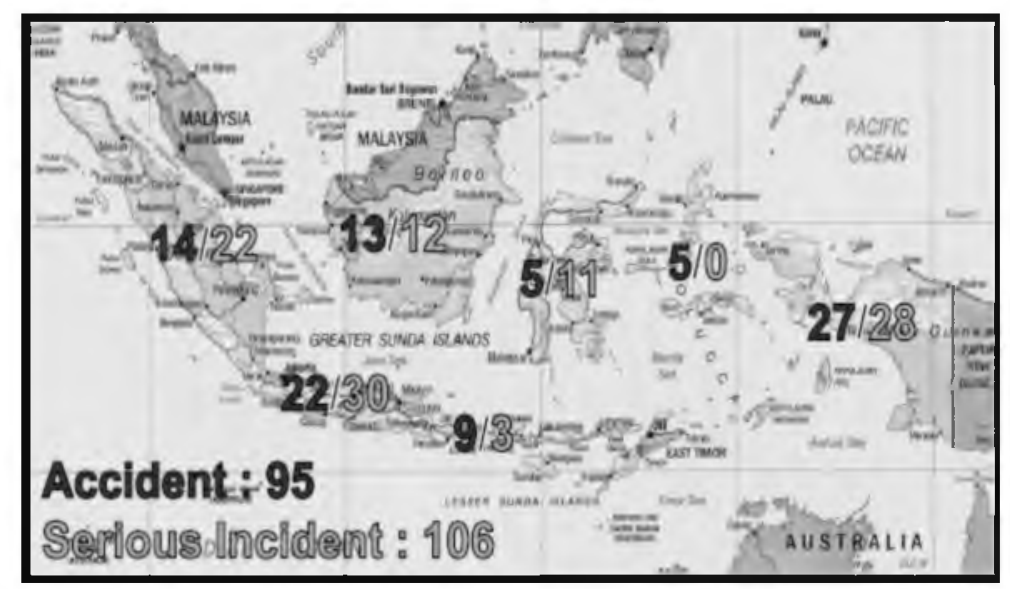

Gambar 9. Peta kejadian accident dan serious incident penerbangan di Indonesia Sumber : Database KNKT 31 Desember 2014 (diolah)

Berdasarkan gambar peta kejadian accident dan serious incident penerbangan di Indonesia untuk periode tahun 2007 - 2014 menunjukkan bahwa wilayah Papua merupakan wilayah yang penting untuk diperhatikan. Kondisi ini terjadi mengingat transportasi udara masih menjadi sarana pokok dalam mendistribusikan segala macam logistik di wilayah tersebut. Wilayah Papua memiliki sebanyak 57 buah bandar udara dengan berbagai tipe dan klasifikasinya, sehingga Ditjen Perhubungan Udara dalam hal ini Direktorat Kelaikudaraan dan Pengoperasian Pesawat Udara harus serius, karena lembaga ini yang mempunyai tugas melaksanakan perumusan dan pelaksanaan kebijakan, penyusunan norma, standar, prosedur, dan kriteria, pemberian bimbingan teknis dan supervisi, serta evaluasi dan pelaporan di bidang kelaikudaraan dan pengoperasian pesawat udara.

Analisis terakhir berkaitan dengan kecelakaan penerbangan di Indonesia adalah analisis berdasarkan jumlah rekomendasi yang telah dikeluarkan oleh KNKT selama periode tahun 2007 sampai dengan tahun 2014. Analisis ini menunjukkan tindak-lanjut dari hasil investigasi tiap kecelakaan penerbangan pada periode waktu tersebut, yang dapat dilihat berdasarkan tabel berikut : 
Tebel 5. Jundah Rekomendasi Yang Dikeluarkan KNKT Taluun 2007 - 2014

\begin{tabular}{|c|c|c|c|c|c|c|c|c|c|}
\hline \multirow[b]{2}{*}{ Tahun } & \multirow[b]{2}{*}{$\begin{array}{c}\text { Jumlah } \\
\text { Kecelakatu }\end{array}$} & \multicolumn{7}{|c|}{ Rekomendasi } & \multirow[b]{2}{*}{ Total } \\
\hline & & $\begin{array}{l}\text { Ditjen } \\
\text { Hubud }\end{array}$ & Operator & Bandlara & $\begin{array}{c}\text { Lembaga } \\
\text { Itrvestigasi } \\
\text { Negata } \\
\text { Laiti }\end{array}$ & $\begin{array}{c}\text { Regulator } \\
\text { Negara } \\
\text { Lain }\end{array}$ & $\begin{array}{l}\text { Pabrik } \\
\text { Pesamat } \\
\text { Udara }\end{array}$ & $\begin{array}{l}\text { Instansi } \\
\text { Launiyya }\end{array}$ & \\
\hline 2007 & 21 & 55 & 29 & 13 & 0 & 1 & 0 & 0 & 98 \\
\hline 2008 & 21 & 32 & 22 & 4 & 0 & 18 & 7 & 0 & 83 \\
\hline 2009 & 21 & 20 & 25 & 2 & 0 & 0 & 1 & 0 & 48 \\
\hline 2010 & 18 & 15 & 19 & 4 & 0 & 0 & 0 & 1 & 39 \\
\hline 2011 & 32 & 39 & $5 ?$ & 5 & 0 & 0 & 1 & 1 & 98 \\
\hline 2012 & 29 & 18 & 19 & 12 & 0 & 4 & 3 & 0 & 56 \\
\hline 2013 & 29 & 27 & 32 & 5 & 0 & 0 & 1 & 12 & 77 \\
\hline 2014 & 30 & 2 & 9 & 3 & 0 & 0 & 0 & 0 & 14 \\
\hline Total & 201 & 208 & 207 & 48 & 0 & 23 & 13 & 14 & 513 \\
\hline
\end{tabular}

Berdasarkan tabel jumlah rekomendasi yang telah dikeluarkan oleh KNKT berdasarkan hasil investigasi yang dilakukannya, maka dapat digambarkan dalam bentuk grafik sebagai berikut:

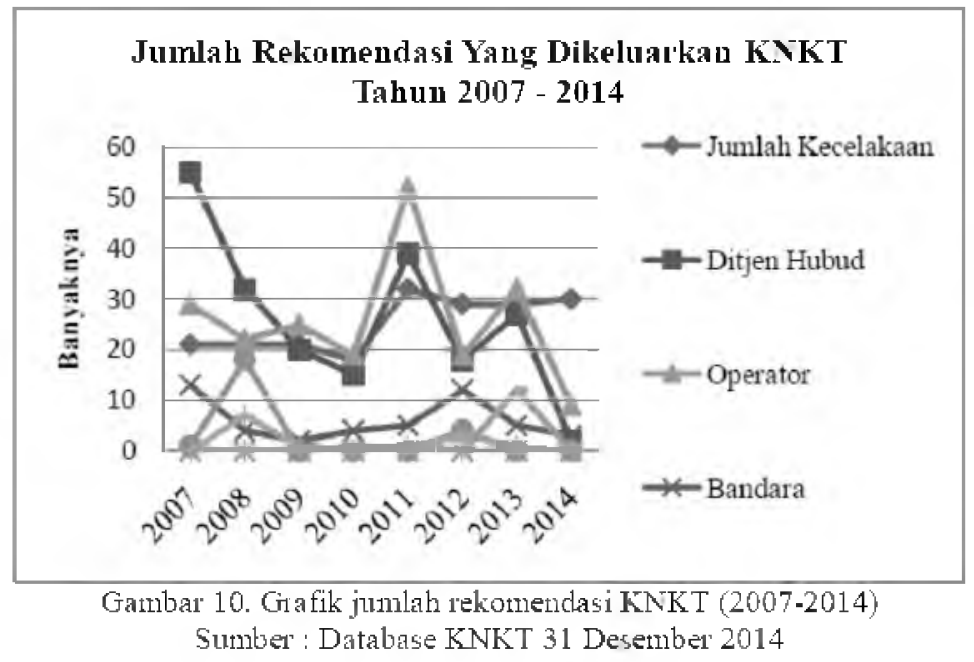

Jumlah rekomendasi yang terbanyak diberikan oleh KNKT kepada Ditjen Perhubungan Udara yaitu sebanyak 208 rekomendasi selama periode tahun 2007-2014 tetapi trennya menurun. Kondisi ini menunjukkan bahwa regulasi yang telah disempurnakan oleh Ditjen Perhubungan Udara menunjukkan hasil yang positif, buktinya tren accident juga mengalami penurunan. Tren serious incident sedikit mengalami peningkatan, buktinya rekomendasi kepada operator juga trennya mengalami peningkatan. Kondisi ini harus ditangani oleh Ditjen Perhubungan Udara dalam hal ini Direktorat Kelaikudaraan dan Pengoperasian Pesawat Udara dengan serius, karena lembaga ini yang mempunyai tugas melaksanakan perumusan dan pelaksanaan kebijakan, penyusunan norma, standar, prosedur, dan kriteria, pemberian bimbingan teknis dan supervisi, serta evaluasi dan pelaporan di bidang kelaikudaraan dan pengoperasian pesawat udara.

Beberapa langkah perbaikan regulasi dan fasilitas penerbangan sudah dilakukan oleh pemerintah dalam hal ini Ditjen Perhubungan Udara sebagai regulator yang menetapkan standar operasional, mengawasi dan mengevaluasi kinerja operasional semua operator pada 
industri penerbangan di Indonesia. Hal ini perlu ditingkatkan lagi mengingat ada kecenderungan pengguna transportasi udara mengalami peningkatan. Hal ini dapat tergambar pada grafik di bawah ini:

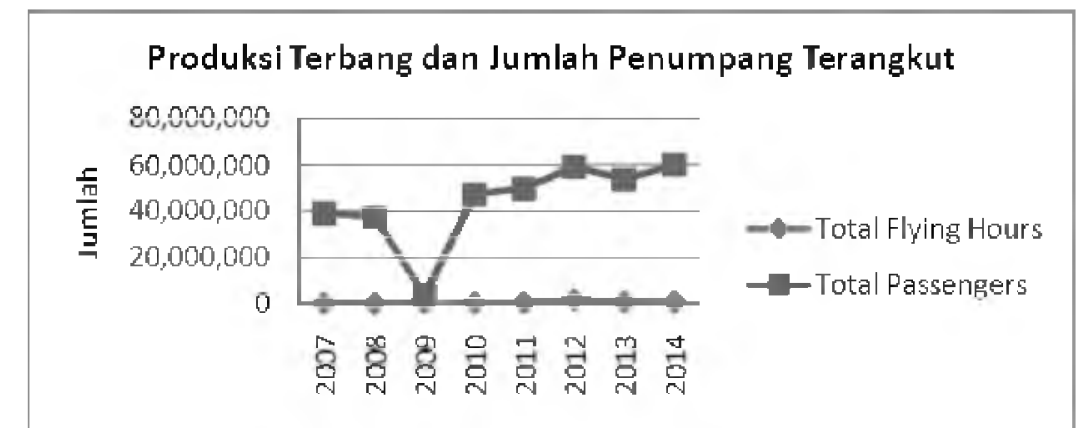

Gambar 11. Gratïk produksi terbang dan jumlialn pemunpang terangkut. Sumber : Database KNKT 31 Desembet 2014 (diolali)

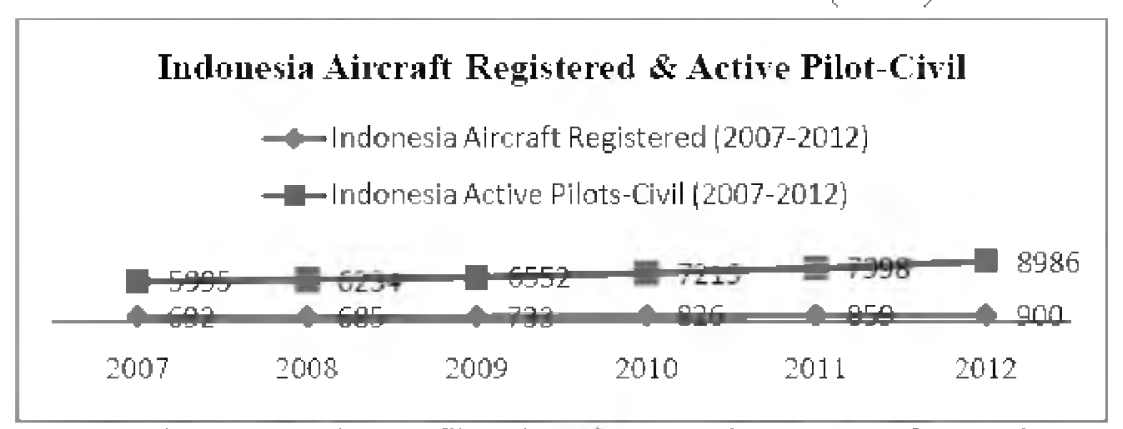

Gambar 12. Gambar grafik Indonesia Amcraft de Active Piot-Cint Sumber : Database KNKI 31 Desember 2014

Berdasarkan gambar grafik produksi terbang dan jumlah penumpang terangkut, serta grafik Indonesia Aircraft \& Active Pilot-Civil maka ada kecenderungan meningkatnya pengguna jasa transportasi udara. Semakin banyak pengguna transportasi udara ini akan cenderung juga meningkatkan jumlah kecelakaan. Kondisi ini harus ditangani oleh Ditjen Perhubungan Udara dalam hal ini Direktorat Kelaikudaraan dan Pengoperasian Pesawat Udara dengan serius, karena lembaga ini yang mempunyai tugas melaksanakan perumusan dan pelaksanaan kebijakan, penyusunan norma, standar, prosedur, dan kriteria, pemberian bimbingan teknis dan supervisi, serta evaluasi dan pelaporan di bidang kelaikudaraan dan pengoperasian pesawat udara. Lembaga ini harus menciptakan sistem keselamatan penerbangan yang menjamin peningkatan keselamatan penerbangan dengan meningkatkan peran state safety programme (SSP) yang telah ditetapkan sesuai undang-undang seperti gambar 13 di bawah ini. 


\section{ANALISIS KECELAKAAN PENERBANGAN DI INDONESIA UNTUK PENINGKATAN KESELAMATAN PENERBANGAN}

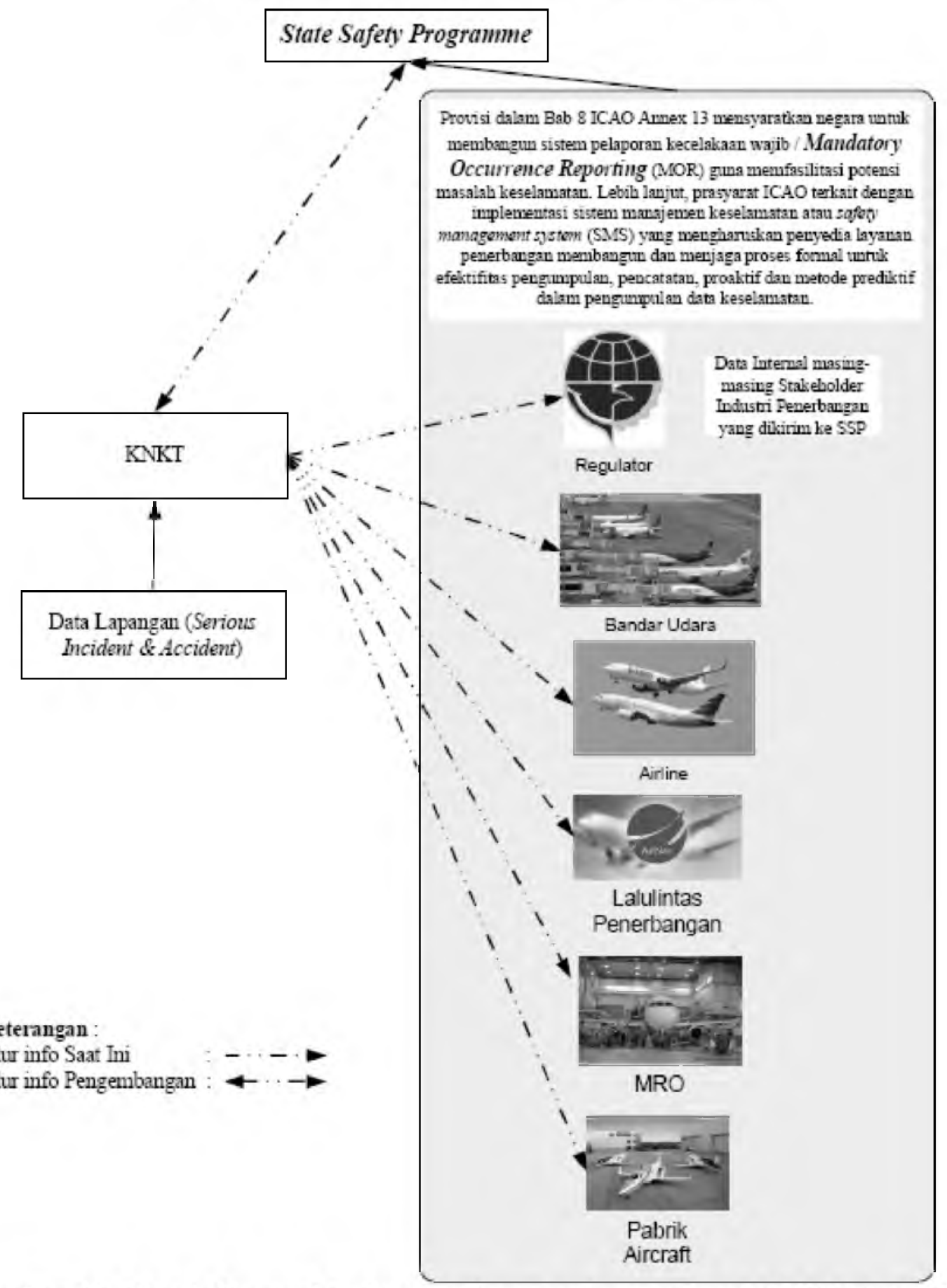

Gambar 13 Alur informasi terintegrasi proses inveastigasi KNKT dan SSP 


\section{Kesimpulan dan Saran}

Berdasarkan hasil dan pembahasan pada sebelumnya, ada beberapa kesimpulan yang dapat diberikan :

1. Klasifikasi yang perlu diperhatikan pada analisis kecelakaan penerbangan adalah "Serious Incident dan Accident". Ada kecenderungan penurunan "Accident" dalam satu sisi, tetapi dalam sisi yang lain ada kecenderungan naiknya "Serious Incident" yang merupakan potensial menjadi "Accident".

2. Perkiraan penyebab kecelakaan penerbangan yang paling dominan adalah faktor manusia persentasenya mencapai $60 \%$. Hal ini menunjukkan tugas yang berat pada Ditjen Perhubungan Udara untuk selalu mengawasi, dan menetapkan standar operasional penerbangan yang dilaksanakan oleh beberapa operator di Indonesia.

3. Lokasi/tempat adanya "Accident dan Serious Incident" yang cukup tinggi di wilayah Indonesia Timur terutama Papua. Kondisi ini perlu menjadi catatan serius karena wilayah ini masih mengandalkan transportasi udara untuk distribusi logistiknya.

4. Jumlah rekomendasi yang terbanyak diberikan oleh KNKT kepada Ditjen Perhubungan Udara yaitu sebanyak 208 rekomendasi selama periode tahun 2007-2014 tetapi trennya menurun. Pada sisi yang lain tren rekomendasi yang diberikan ke operator menunjukkan kenaikan. Hal ini menunjukkan perlunya peningkatan pengawasan kepada operator oleh Ditjen Perhubungan Udara dalam hal ini Direktorat Kelaikudaraan dan Pengoperasian Pesawat Udara dengan serius, karena lembaga ini yang mempunyai tugas melaksanakan perumusan dan pelaksanaan kebijakan, penyusunan norma, standar, prosedur, dan kriteria, pemberian bimbingan teknis dan supervisi, serta evaluasi dan pelaporan di bidang kelaikudaraan dan pengoperasian pesawat udara.

Berdasarkan kesimpulan seperti diuraikan di atas, maka beberapa saran yang dapat diberikan pada penelitian ini:

1. Penelitian dapat dilanjutkan dengan mengoptimalkan state safety programme (SSP) sesuai dengan program dari ICAO, sehingga jaminan keselamatan penerbangan dapat ditingkatkan.

2. Mengingat human factor merupakan kontribusi dominan terjadinya kecelakaan pesawat udara. Penelitian dapat dikembangkan mengamati hal tersebut untuk peningkatan keselamatan penerbangan di Indonesia.

\section{Ucapan Terima Kasih}

Penulis sangat berterima kasih atas bantuan KNKT dan Ditjen Perhubungan Udara dalam hal ini DKPPU yang telah memberi kesempatan pada peneliti untuk melakukan survei. 


\section{Daftar Pustaka}

Amalberti, R. (2001) The paradoxes of almost totally safe transportation systems. Safety Science. 37. pp 109-126.

Boeing (2011), "Statistical Summary of Commercial Jet Airplane Accidents Worldwide Operation 1959-2010", Boeing Commercial Airplanes, Seattle.

Cheng, W., Washington, S.P., (2005), "Experimental evaluation of hotspot identification methods", Accident Analysis and Prevention, 37. pp 870- 881.

Christian, E., (2010)., Pengukuran Kinerja Perusahaan Jasa Penerbangan Di Indonesia Dengan Metode Performance Prism., Tesis Program Studi Teknik Industri, Fakultas Teknik, Universitas Indonesia, Depok, Juni 2010

Elvik, R. (2008), "The predictive validity of empirical Bayes estimates of road safety", Accident Analysis and Prevention, 40. pp 1964-1969.

Fikarno, D.A., (2009)., Faktor-Faktor Penyebab Rendahnya Keselamatan Penerbangan Di Indonesia., Tesis Magister Perencanaan dan Kebijakan Publik, Program Pascasarjana, Fakultas Ekonomi, Universitas Indonesia, Depok, 2009.

Khairandy, Ridwan, 2006. "Tanggung Jawab Pengangkut dan Asuransi Tanggung Jawab Sebagai Instrumen Perlindungan Konsumen Angkutan Udara, Jurnal Hukum Bisnis Vol. 25, No.1, Jakarta, Yayasan Pengembangan Hukum Bisnis, Hal. 21.

Khairumusa, A.R., (2012), Analisa Tingkat Kerawanan Bandar Udara Berdasarkan Kejadian Kecelakaan dan Insiden Serius di Indonesia, Tesis Program Studi Teknik Sipil Kekhususan Transportasi, Universitas Indonesia, Depok, Juli 2012

Kementerian Perhubungan (2012), "UU No.1 Tahun 2009 Tentang Penerbangan".

ICAO (2009), Safety Management Manual (SMM), Doc 9859, AN 474, Second edition, International Civil Aviation Organization, Montreal.

ICAO (2010), "Annex 13 Aircraft Accident and Incident Investigation", Tenth Edition, International Civil Aviation Organization, Montreal.

International Society of Air Safety Investigators (ISASI), Positions On Air safety Investigation Issues, Third Edition, 24 Agustus 2003.

Netjasov, F., \& Janic, M. (2008). A Review of Research on Risk and Safety Modelling in Civil Aviation. Journal of Air Transport Management, 14, 213-220

Reason, J. (1997), "Managing the Risks of Organizational Accidents" Ashgate Publishing Limited, Aldershot, England.

Reason, J., (1998). Achieving A Safe Culture : Theory And Practice, Work \& Stress Vol. 12, NO. 3 293-306, UK : Department of Psychology, University of Manchester, 1998.

Sentot S., (2012), Analisis Resiko Kecelakaan pada Kegiatan Pelayanan Sisi Udara Pesawat Udara di Bandara Soekarno-Hatta, Tesis Peminatan Keselamatan Kesehatan Kerja, Fakultas Kesehatan Masyarakat, Universitas Indonesia.

Silvia, M., (2014)., Pengaruh Service Quality Terhadap Customer Satisfaction dan Behavioral Intention pada Industri Penerbangan Low Cost Carriers Rute Domestik di Surabaya, : Jurnal Ilmiah Mahasiswa Universitas Surabaya Vol.3 No.2 (2014) 
Wardani. E.K., (2006)., Pengukuran Tingkat Kepuasan Konsumen Jasa Penerbangan (Studi Kasus pada Jasa Penerbangan Garuda Indonesia Semarang-Jakarta)., Jurnal Studi Manajemen \& Organisasi, Volume 3, Nomor 1, Januari, Tahun 2006, Halaman 40

Wiradipradja., S (2006), Tanggung Jawab Perusahaan penerbangan Terhadap Penumpang Menurut hukum udara Indonesia, Jurnal hukum Bisnis, Volume 25, No.1, tahun 2006., hal.5

Wastuadhi, A.P., (2012)., Penyelenggaraan Penyelidikan Dalam Mencari Penyebab Kecelakaan Pesawat Udara Sipil Yang Terjadi Di Wilayah Indonesia, Tesis Fakultas Hukum, Program Pascasarjana, Kekhususan Sistem Peradilan Pidana, Universitas Indonesia, Jakarta, Juli 2012. 1999. Guidelines for Investigator Training and Education, First Edition, Agustus

International Civil Aviation Organization (ICAO) dan Commercial Aviation Safety Team (CAST), Aviation Occrrence Categories, Definitions and Usage Notes, May 2011.

Human error: models and management, Department of Psychology, University of Manchester, Manchester M13 9PL, British Medical Journal, BMJ.18 March 2000; 320(7237): 768-770. 